\title{
A Profile of the Health-Promoting Behaviors of Physicians and Lawyers
}

\section{Citation}

Wyshak, Grace, George A. Lamb, Robert S. Lawrence, and William J. Curran. 1980. "A Profile of the Health-Promoting Behaviors of Physicians and Lawyers." N Engl J Med 303 (2) (July 10): 104-107. doi:10.1056/nejm198007103030210.

\section{Published Version}

doi:10.1056/NEJM198007103030210

\section{Permanent link}

http://nrs.harvard.edu/urn-3:HUL.InstRepos:16953386

\section{Terms of Use}

This article was downloaded from Harvard University's DASH repository, and is made available under the terms and conditions applicable to Other Posted Material, as set forth at http:// nrs.harvard.edu/urn-3:HUL.InstRepos:dash.current.terms-of-use\#LAA

\section{Share Your Story}

The Harvard community has made this article openly available.

Please share how this access benefits you. Submit a story.

\section{Accessibility}


ic, they should have had an immune response very early. The appearance of antibodies so late (after eight weeks) in four of nine patients suggests that they were secondary to hepatocyte damage, not primary in the pathogenesis of hepatocytolysis. In support of this possibility, recent studies by Smith et al..$^{7,8}$ demonstrated a specific cellular immune response to livercell antigens (but not to kidney or spleen-cell antigens) in mice with nonimmunologic liver injury induced by carbon tetrachloride. Sensitized lymphocytes from affected mice did not cause hepatocellular necrosis when administered to syngeneic mice. Similarly, mice depleted of their $\mathrm{T}$ lymphocytes did not have cellular immune responses to liver antigens, but toxic hepatitis did develop. Thus, despite the specificity of cellular immune responses to liver antigens in vitro, these responses appear to have resulted from the liver injury, not to have participated in its pathogenesis.

Although features of hypersensitivity characterize some cases of halothane hepatitis, evidence is evolving that halothane may be a direct hepatotoxin. The centrizonal necrosis seen in many cases is characteristic of true hepatotoxicity, halothane has been shown to be toxic to cultured hepatocyte membranes, and several animal models of halothane hepatotoxicity have been described. Moreover, the fact that toxicity can be enhanced by pretreatment of animals with microsomal-enzyme inducers suggests that toxic metabolites, rather than the parent compound, mediate the damage. Distinctions drawn in the past between "hypersensitivity" hepatitis and hepatotoxicity have been undermined by evidence that toxic metabolites may cause such drug-induced liver diseases as isoniazid hepatitis, originally classified as a "hypersensitivity" reaction. ' Therefore, a designation more appropriate for halothane hepatitis than "hypersensitivity" would be "idiosyncrasy." 10 Such a label would accommodate cases with features of hypersensitivity that may represent an idiosyncratic allergic reaction to halothane as well as those that may represent metabolic idiosyncrasy with enhanced production of a toxic metabolite. Controversy over the mechanism for halothane hepatitis, however, will probably continue until the existence of toxic metabolites in vivo is proved or the primary role of allergy to hepatocyte-membrane antigens is established.

Massachusetts General Hospital Boston, MA 02114

\section{Jules L. Dienstag, M.D.}

\section{REFERENCES}

1. Klatskin G, Kimberg DV. Recurrent hepatitis attributable to halothane sensitization in an anesthetist. N Engl J Med. 1969; 280:515-22.

2. Wright R, Eade OE, Chisholm M, et al. Controlled prospective study of the effect on liver function of multiple exposures to halothane. Lancet. $1975 ; 1: 817-20$.

3. Hughes M, Powell LW. Recurrent hepatitis in patients receiving multiple halothane anesthetics for radium treatment of carcinoma of the cervix uteri. Gastroenterology. 1970; 58:790-7.

4. Trowell J, Peto R, Smith AC. Controlled trial of repeated halothane anaesthetics in patients with carcinoma of the uterine cervix treated with radium. Lancet. 1975; 1:821-4.
5. Klastin G. Mechanisms of toxic and drug-induced hepatic injury. In: Fink BR, ed. Toxicity of anesthetics. Baltimore: Williams \& Wilkins, 1968:159-75.

6. Vergani D, Tsantoulas D, Eddleston ALWF, Davis M, Williams $\mathbf{R}$ Sensitisation to halothane-altered liver components in severe hepatic necrosis after halothane anaesthesia. Lancet. 1978; 2:801-3.

7. Smith CI, Cooksley WGE, Powell LW. Cell-mediated immunity to liver antigen in toxic liver injury. I. Occurrence and specificity. Clin Exp Immunol. 1980; 39:607-17.

8. Idem. Cell-mediated immunity to liver antigen in toxic liver injury. II. Role in pathogenesis of liver damage. Clin Exp Immunol. 1980; 39:61825.

9. Mitchell JR, Zimmerman $\mathrm{HJ}$, Ishak KG, et al. Isoniazid liver injury: clinical spectrum, pathology, and probable pathogenesis. Ann Intern Med. 1976; 84:181-92.

10. Zimmerman HJ. Hepatotoxicity: the adverse effects of drugs and other chemicals on the liver. New York: Appleton-Century-Crofts, 1978:349. 94.

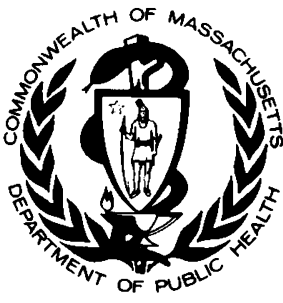

\section{MASSACHUSETTS DEPARTMENT OF PUBLIC HEALTH}

\author{
Edited by \\ Alfred L. Frechette, M.D., M.P.H. \\ and Pearl K. Russo
}

\section{A PROFILE OF THE HEALTH-PROMOTING BEHAVIORS OF PHYSICIANS AND LAWYERS}

\author{
Grace Wyshak, Ph.D., \\ George A. Lamb, M.D., \\ Robert S. LaWrence, M.D., \\ and William J. Curran, J.D., LL.M., S.M.Hyg.
}

The federal government has increased its activities directed toward health promotion and disease prevention.* We carried out a pilot survey of a random sample of Massachusetts physicians and lawyers to obtain a profile of the personal health-promoting behaviors in the two professional groups.

\section{Methods}

A questionnaire was sent to random samples of lawyers from the 1978 roster of the Massachusetts Board of Bar Examiners and of physicians from the 1978 computerized list of licensed and registered physicians in the state, obtained from the Massachusetts Department of Public Health. We used a random-number generator to select the samples. Out-of-state residents appearing on the Massachusetts computer tapes were eliminated from the study. During the week of May 14, 1979, ques-

From the Department of Preventive and Social Medicine, Harvard Medical School, Boston, MA 02115, where reprint requests should be addressed to Dr. Wyshak.

Supported in part by a grant to Dr. Wyshak from the William F. Milton Fund of Harvard University.

Dr. Lamb is currently Professor of Pediatrics, Boston University School of Medicine.

*Healthy People - The Surgeon General's Report on Health Promotion and Disease Prevention. Washington, D.C.: Government Printing Office, 1979. (DHEW [PHS] Publication No. 79-55071). 
tionnaires were sent to 462 physicians and 500 lawyers. A follow-up questionnaire was sent during the week of June 18, 1979 (further details on the sampling procedure are available on request).

The questionnaire sought information on demographic and social characteristics, physical activities (both recreational and nonrecreational), actions related to safety (use of seat belts, handguns, and rifles in the home), dietary habits, sleeping habits, medical and family history, work satisfaction, and the use of tobacco, alcohol, and drugs.

\section{RESUlts}

The response rate, on the basis of one follow-up mailing, was over 65 per cent for both physicians and lawyers. When incorrect addresses and undelivered letters were excluded, the response rate was 70 per cent for physicians and 67 per cent for lawyers. The analysis that follows is based on usable responses from 289 physicians and 316 lawyers. (Questionnaires received after August 1, 1979 were not included.) The responding physicians are similar in age to Massachusetts physicians as a group (further information is available on request).

\section{Demographics (Table 1)}

As expected, physicians and lawyers are similar in their personal and social characteristics - sex, marital status, number of children (living with them), weight, height, and weight change since graduating from college. The lawyers tended to be about $2 \frac{1}{2}$ years younger than the physicians and to have graduated later from college and law school. Ninety per cent of the responding physicians and 93 per cent of the responding lawyers reported being in active practice at the time of the survey. There were, however, some noteworthy differences. Total family income was higher among physicians. The gap in income was greatest among those under 40 years of age and had largely disappeared among those 55 years of age and older. The two groups differed in their stated religious preference: more physicians checked "none" or "Protestant," and more lawyers, "Catholic." Physicians were more likely to have attended Ivy League schools, whereas lawyers had more often attended non-Ivy League private institutions.

Table 1. Characteristics of 289 Physicians and 316 Lawyers.

\begin{tabular}{lcc}
\multicolumn{1}{c}{ Characteristic } & Physicians & Lawyers \\
& \multicolumn{2}{c}{ PER CENT } \\
& \multicolumn{2}{c}{10} \\
Female & 8 & 10 \\
Married & 6 & 8 \\
Divorced or separated & 6 & 10 \\
Single (never married) & 39 & 48 \\
Under 40 years of age & 32 & 29 \\
40 to 54 years of age & 29 & 23 \\
55 years of age and over & $\$ 55,600$ & $\$ 42,000$ \\
Total family income (median) & &
\end{tabular}

Table 2. Physical Activities Performed at Least Once in a Two-Week Period.

\begin{tabular}{lcc}
\multicolumn{1}{c}{ Activity } & Physicians & Lawyers \\
& \multicolumn{2}{c}{ PER CENT } \\
& 73 & 76 \\
At least one activity & 54 & 57 \\
Gardening & 31 & 34 \\
Jogging & 24 & 32 \\
Calisthenics & 24 & 25 \\
Racquetball & 12 & 17 \\
Golf & 16 & 14 \\
Bicycling & & \\
\hline
\end{tabular}

\section{Physical Activities}

Slightly fewer physicians engaged in exercise, sports, and recreational physical activities during the two-week period for which information was sought. However, about three fourths of the respondents in both groups reported engaging in at least one activity. Gardening was by far the most widely done. Jogging was the most popular vigorous physical activity, followed by calisthenics. For each activity that was reported by at least 10 persons, the proportion doing it at least once was greater among lawyers; the single exception was bicycling (Table 2).

In terms of the mean number of times an activity was practiced, the two groups are virtually identical except for gardening. Physicians who gardened did so on an average of 4.2 times in a two-week period (during May and June), and lawyers 3.4 times $(\mathrm{P}<0.05)$. As expected, vigorous physical activities showed a gradient with age, but gardening showed no relation with age.

Although physicians were less likely to take part in recreational physical activities, they were more apt to engage in nonrecreational physical activities. They reported climbing an average of 10.3 flights of stairs per day versus 7.8 flights among lawyers $(\mathrm{P}<0.001)$ and walking the equivalent of 12.2 blocks per day versus 10.4 blocks among lawyers $(P=0.06)$.

\section{Safety and Accident Precautions}

The one health-promoting practice that showed the greatest difference between physicians and lawyers was the use of seat belts in automobiles. Nearly every respondent reported some travel by car. The median number of miles traveled in the preceding two weeks was slightly greater among lawyers - 380 miles as compared with 350 miles for physicians. But physicians reported using seat belts more frequently than did lawyers. Younger persons (under 40 years of age) in both professional groups were more likely to use seat belts than were older persons ( 55 years of age and over). Possibly; the experience of physicians in emergency rooms accounts for their greater recognition of the value of seat belts. Smaller cars, more frequently owned and driven by younger persons, may explain at least in part the age relation. 
Rifles in the home were reported by 15 per cent of physicians and 18 per cent of lawyers; ownership increased with age. In both groups, one in eight reported having handguns.

\section{Smoking Habits}

Nearly 90 per cent of the respondents do not smoke pipes, cigars, cigarillos, or combinations of these. Among those who do smoke, pipes are the most commonly used. Physicians showed a slight preference for pipes, whereas lawyers showed a slightly greater preference for cigars and cigarillos.

Cigarette smoking is not popular with either group. Eighty-six per cent of the physicians and over 80 per cent of the lawyers do not now smoke cigarettes daily. Physicians under 40 years of age are more likely to be nonsmokers than are their older colleagues. Among lawyers, the reverse holds - lawyers 55 years of age and over are less likely to be smokers than are those under 40 years of age (Table 3). Overall, of those who do not smoke now, nearly one half have never smoked; persons who have never smoked tend to be in the younger age group.

Another interesting difference between the two professional groups is the age at which smoking was started. Among current and former smokers, lawyers started smoking at a younger age. Lawyers, both current and former smokers, also smoked more cigarettes per day.

In summary, smoking is not popular in either group, but physicians have a more favorable record in the three categories - not smoking now, never having smoked, and the number of cigarettes smoked. In particular, younger physicians have more favorable habits with respect to smoking than do lawyers of comparable age.

\section{Drinking Behavior}

Nearly everyone in the two groups ( 90 per cent) drinks at least once a month or more often, and only one in 25 is a teetotaler (no drinks at all in the past 12 months). Lawyers, however, tend to drink more often and to drink more when they do drink. In addition, the day of the week on which drinking is done differs between physicians and lawyers. Mid-week drinking is not prevalent - half of those reporting in both groups did not have any drinks on "last Tuesday," but over a third of the lawyers and one fifth of the physicians had more than one drink. Saturday and Sunday drinking show more striking and statistically significant differences. Drinking, common in both groups, is heavier among lawyers, perhaps because of the nature of their profession and the resultant "threemartini lunch" syndrome.

Most respondents' drinking patterns did not change during the past year; types of drink are about the same, although physicians show a slight preference for wine, and lawyers for beer. The numbers are small, but a few more lawyers reported problems with drinking -9 per cent as compared with 3 per cent for physicians. Problems reported were mostly tension or disagreements with family or friends. There are virtually no former drinkers - the overwhelming majority of respondents drink to some extent.

\section{Health Habits}

Most of the respondents eat breakfast at least sometimes; only 4 per cent never do. Very few use antidepressants ( 3 per cent); 25 per cent report that they meditate. Physicians are slightly more likely to use tranquilizers, and a statistically higher number use sleeping pills.

More physicians report that they observe dietary restrictions - 50 per cent as compared with 40 per cent of the lawyers checked at least one restriction. Not surprisingly, of those with dietary restrictions, more lawyers' diets were ordered by a doctor or nutritionist. The most commonly reported item is low fat, followed by low salt and low calorie. One and one half per cent reported that they were vegetarians.

Table 3. Cigarette Smoking, According to Age, among Physicians and Lawyers.

\begin{tabular}{lcc}
\hline SMoking Habits & Physicians & LAWYers \\
& \multicolumn{2}{c}{ PER CENT } \\
& \multicolumn{2}{c}{} \\
Do not smoke now & 91 & 79 \\
Under 40 years of age & 86 & 77 \\
40 to 54 years of age & 84 & 84 \\
55 years of age and over & & \\
Never smoked & 65 & 55 \\
Under 40 years of age & 50 & 37 \\
40 to 54 years of age & 36 & 40 \\
55 years of age and over & & \\
\end{tabular}

\section{Medical History}

The two groups are generally similar in their medical histories, with several important exceptions. In answer to questions relating to conditions about which they had been told by a physician, 21 per cent of the lawyers as compared with 12 per cent of the physicians reported hypertension. In each of three broad age groups - under 40,40 to 54 , and 55 years of age and over - more lawyers reported hypertension than did physicians. Degenerative arthritis and prostate disease were more frequently reported by physicians.

Half or more of the respondents reported on their parents' medical history. Some noteworthy differences were found. Physicians' mothers were more likely to have a history of coronary heart disease. This finding could be real or the result of better reporting on the part of physicians. Nearly half of each group reported on their fathers' cause of death. Physicians' fathers were more likely to die of cancer, and lawyers' fathers of cardiovascular disease; other causes of death were similar in the two groups. 


\section{WORK SITUation}

It has been predicted that perhaps lawyers, trial lawyers in particular, would think that their work was stressful. In fact, lawyers did report more pressure in their practices than did physicians (Table 4). Significantly more lawyers than physicians rated the pressure in their work as high on a three-point scale low, medium, or high. Lawyers are also less happy with their practices, especially younger lawyers as compared with physicians in the same age group. However, by the age of 55 years and over, differences in "happiness" largely disappear.

It is possible that lawyers compensate for the stress and greater work dissatisfaction by sleeping more. Significantly more lawyers than physicians sleep eight hours or more per 24 hours. Physicians not only sleep less, but they also work more hours per week and spend more time working outside regular hours.

When physicians work, they work longer hours, sleep less, have more income, and seem to have less time for recreational activities than do their legal counterparts, but they may recharge their energies by

Table 4. Features of the Work Situations of Physicians and Lawyers.

\begin{tabular}{lcc}
\hline \multicolumn{1}{c}{ Feature } & Physicians & LAWYers \\
& \multicolumn{2}{c}{ PER CENT } \\
& 37 & 45 \\
High pressure in practice & 63 & 53 \\
Very happy/happy with practice & 33 & 10 \\
Work 60 or more hours per week & 29 & 21 \\
Work 9 or more hours per week beyond & & 30 \\
regular hours & 61 & 30 \\
Four or more weeks of vacation per year & 23 & \\
Sleep 8 or more hours per 24 & & \\
\hline
\end{tabular}

taking more vacation time. Of those not retired or unemployed, over 50 per cent of physicians reported four weeks or more of vacation per year; only 30 per cent of the lawyers reported the same amount of vacation time.

\section{Combination of Risk Factors}

A three-item scale of factors commonly used in risk appraisal - smoking, use of seat belts, and jogging showed that slightly more physicians than lawyers had favorable practices on the three items (14 vs. 9 per cent). At the other end of the scale, 8 per cent of the physicians and 12 per cent of the lawyers were negative on all three items.

\section{Discussion}

In addition to suggesting several areas for further research, the results of this pilot survey show that physicians seem to be more concerned than lawyers with personal health-promoting behaviors. More importantly, physicians are in a position to educate and promote favorable health practices in their patients.

\section{CORRESPONDENCE}

Letters to the Editor are considered for publication (subject to editing and abridgment), provided they are submitted in duplicate, signed by all authors, typewritten in doublespacing, and do not exceed $1 \frac{112}{2}$ pages of text. Letters referring to a recent Journal article should be received within six weeks of the article's publication date. We are unable to provide prepublication proofs, and unpublished material will not be returned to authors unless a stamped, self-addressed envelope is enclosed.

\section{FACIAL DYSKINESIA FROM OVERDOSE OF AN ANTIHISTAMINE}

To the Editor: Two previous reports in the Joumal ${ }^{1,2}$ have suggested that oral facial dyskinesias may occasionally be associated with short-term use of an antihistamine. In both cases the possibility of a hysterical origin was entertained and could not be absolutely excluded, although it was dismissed as very unlikely. Sovner, ${ }^{3}$ in a subsequent letter to the fournal, suggested that the facial movements actually represented an acute dystonic reaction to antihistamine.

We now describe an 18-month-old girl who presented for medical evaluation approximately 12 hours after ingesting four Drixoral tablets $(6 \mathrm{mg}$ of dexbrompheniramine maleate and $120 \mathrm{mg}$ of pseudoephedrine sulfate per tablet). Initial examination revealed intermittent bilateral trismus, frequent tongue protrusion, and associated spasms of the platysma. Blood pressure was $120 / 90 \mathrm{~mm}$ $\mathrm{Hg}$, with a pulse of 200 per minute. The pupils were dilated at 8 $\mathrm{mm}$ bilaterally and were reactive to light. The child was very irritable and cried intermittently. She was admitted to the hospital for observation and gradually improved over 12 hours, with vital signs returning to normal and total resolution of involuntary faciallingual movements. The medical history and family history were totally unremarkable, and the child has remained normal.

This case provides further evidence of an occasional association of an oral and facial-movement disorder with short-term antihistamine use; the age of the patient eliminates hysteria as a possible cause of the problem. We think that the abnormal movements are best described as an acute oral and facial dystonic reaction. The initially abnormal vital signs also indicated sympathomimetic overdose, but there is no reason to implicate the sympathomimetic agent as the cause of the movements.

Donald A. Barone, D.O. John Raniolo, D.O College of Medicine and Dentistry of New Jersey New Jersey School of Stratford, NJ 08084 Osteopathic Medicine

1. Favis GR. Facial dyskinesia related to antihistamine? N Engl J Med. 1976; 294:730.

2. Brait KA, Zagerman AJ. Dyskinesias after antihistamine use. $\mathbf{N}$ Engl $\mathbf{J}$ Med. 1977; 296:111.

3. Sovner R. Antihistamine-induced extrapyramidal reactions. N Engl J Med. 1977; 296:633-4.

\section{"SINUTABS" FOR CLUSTER HEADACHE}

To the Editor: Cluster headache (also called Horton's headache or histamine headache) is characterized by severe unilateral paroxysmal pain, which may not respond to the drugs used to treat other vasomotor disturbances such as migraine. Many patients with this condition turn to unorthodox forms of treatment. I recently became aware of one such self-prescribed remedy being used by a clusterheadache sufferer - Sinutabs decongestant tablets. This agent contains a combination of ingredients including acetaminophen, phenyltoloxamine citrate, and phenylpropanolamine hydrochlo- 